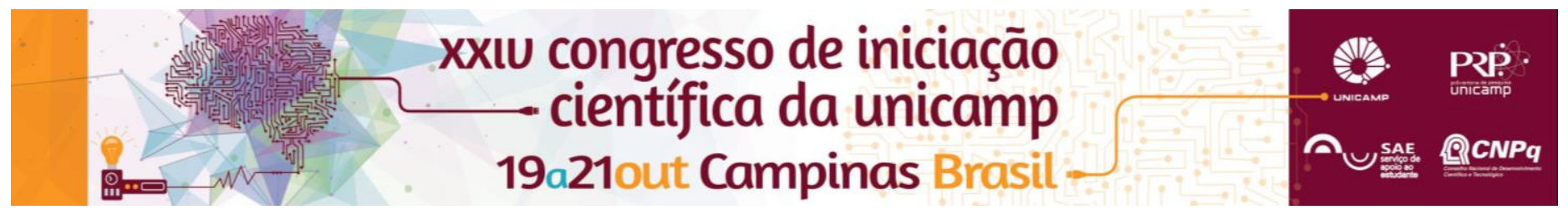

\title{
Impactos socioeconômicos do plano de investimentos do setor de petróleo na economia brasileira
}

\author{
Gabriele C. de Souza*, Marcelo P. da Cunha.
}

\begin{abstract}
Resumo
O uso de energia fóssil, desde a revolução industrial, trouxe à humanidade um grau de desenvolvimento sem precedentes nos últimos 250 anos. No Brasil, petróleo e derivados representaram a maior parcela de toda a oferta interna do país em 2013, com 39,3\%. O setor de petróleo brasileiro apresentou um desenvolvimento acentuado a partir de 1953, quando foi fundada a Petrobras (Petróleo Brasileiro S.A). O aumento expressivo da produção de petróleo doméstico traz, além dos benefícios econômicos e estratégicos (este último por conta da redução da dependência energética externa) relativos ao setor energético e à balança comercial, impactos socioeconômicos relevantes em toda a cadeia produtiva nacional associada aos investimentos (formação bruta de capital fixo) necessários para aumentar sua capacidade, especialmente os investimentos necessários para explorar os recursos descobertos no pré-sal. O objetivo desta pesquisa é avaliar os impactos na economia brasileira, decorrentes do plano de investimentos da Petrobras para o período de 2013 a 2017, em termos (i) do nível da produção setorial, (ii) dos empregos gerados, (iii) da renda gerada e do (iv) produto interno bruto (PIB). A análise de insumo-produto será empregada como metodologia principal para captar todos os efeitos diretos e indiretos para atender a demanda requerida neste plano de investimento.
\end{abstract}

\section{Palavras-chave:}

Petróleo; investimentos; análise de insumo-produto.

\section{Introdução}

O setor energético é reconhecido por sua importância estratégica para 0 desenvolvimento econômico das nações. Ainda que ao uso das fontes fósseis de energia esteja associada a maior parte das emissões antrópicas de gases de efeito estufa (GEE), o seu emprego, do ponto de vista econômico, é muito relevante nas economias de diversas nações. No Brasil, a confirmação da existência do produto mineral no país, pelo governo federal, ocorreu em 1936; a partir disso, em 1938, foi criado pelo então presidente, Getúlio Vargas, o Conselho Nacional do Petróleo (CNP), com a finalidade de regulação e estruturação da exploração do petróleo no país.

Nos anos 1970, o consumo de derivados no país já impulsionava o crescimento de mais de $10 \%$ ao ano do Produto Interno Bruto (PIB) e, em 1973, devido à primeira crise do petróleo e o consequente aumento dos seus preços, o governo adotou medidas para diminuir a dependência da importação de petróleo (que foi de $84,1 \%$, em média, na década de 1970 (EPE, 2014)) - dentre elas a criação do Programa Nacional do Álcool - e continuou a investir na exploração marítima.

Em novembro de 2007, a Petrobras fez o anúncio das descobertas de reservas gigantes de petróleo de qualidade no pré-sal brasileiro. Com esta descoberta, o país possui uma das 10 maiores reservas de petróleo do mundo, apresentando potencial para ser um grande exportador do óleo.

Não há dúvida da importância do aumento da capacidade de extração e refino de petróleo para a economia brasileira; a mensuração e caracterização desta importância deve levar em consideração, também, todos os impactos decorrentes dos efeitos socioeconômicos gerados na cadeia produtiva doméstica por conta da produção dos bens de capital, construção civil e serviços de engenharia necessários (e desenvolvidos) para explorar do melhor modo possível as reservas desta riqueza energética.
O objetivo principal deste projeto é avaliar, em termos quantitativos, os impactos socioeconômicos, na economia brasileira, do plano de investimentos da Petrobras relativo ao período de 2013 a 2017, cujo valor total, anunciado em 2013, soma US\$236,7 bilhões (PETROBRAS, 2013). Empregando-se a análise de insumo-produto, será possível quantificar, levando-se em consideração todos os efeitos diretos e indiretos ao longo das cadeias produtivas domésticas, os impactos da parcela não realizada deste programa para a economia desagregada em 68 setores produtivos, em termos do (i) nível da produção setorial, (ii) dos empregos gerados, (iii) da renda gerada e do (iv) produto interno bruto (PIB).

\section{Resultados e Discussão}

O valor total que deixou de ser investido no período 2013-2017 foi de US\$75.537.500.000,00, sendo que US\$47.071.319.180,40 foi referente ao segmento de petróleo e gás natural e US\$28.466.180.819,60 referente ao segmento de refino de petróleo e coque. A partir da análise insumo-produto, foi possível concluir que essa redução de investimento poderia ter gerado uma produção de US\$78.838 milhões, além de US\$43.510 milhões ao PIB preços básicos e 78.838 empregos. Dentre a variação da produção 40,2\% decorreria de efeitos indiretos, enquanto em relação ao aumento de emprego $42,6 \%$ resultariam, também, de efeitos indiretos.

\section{Conclusões}

O setor de petróleo, e no caso brasileiro, a Petrobras, deve ser estrategicamente analisado não apenas por produzir a mais importante fonte de energia primária, mas também por sua capacidade de impactar toda a cadeia produtiva nacional associada aos investimentos necessários para aumentar sua capacidade. Sua expansão associa-se à geração de empregos, aumento da produção e da renda nacional. 